\title{
IV. Alatį̧ent.
}

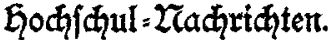

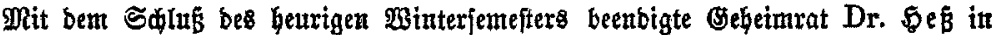

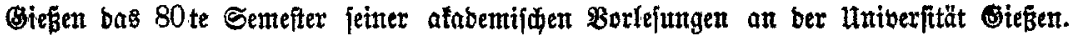

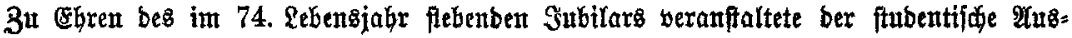

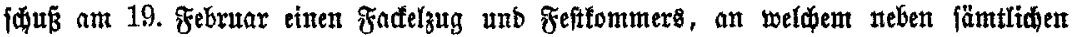
ftubentifiden sorporntionen aud bie Mebrzahl ber zur Feier zablreid eingetroffenen frïberent Sdüler bes (senannten, bie befiffdien Forftbeamten, teilnngmen. Bei bem

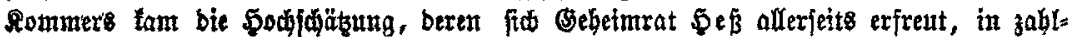

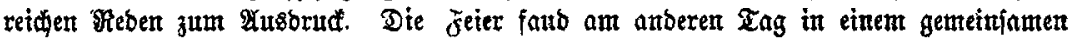
Spaziergang in ben alabemifden Forftgarten anf bem Sqiffenberg, an bem fit now

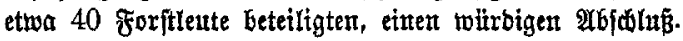

II. Bayerijhe Eeweihausftellung pom 18. 2upril bis 15. Mai 1909.

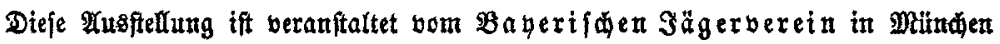

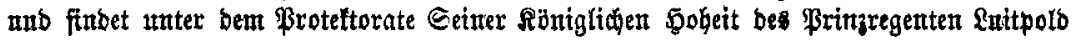
won Bayern ftatt.

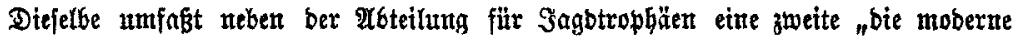

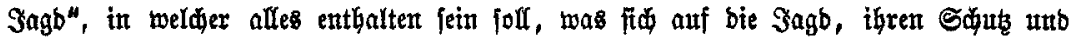
ibre Sege beżiebt, unb foll biefe II. 2atteilung umfaffen:

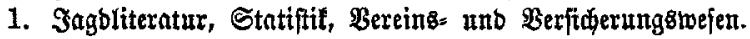

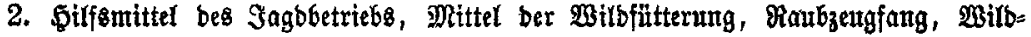
gatter, Ranjeln, Sdirme, Sappen ufm.

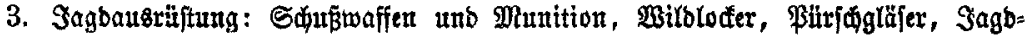
tleibung, Froviant, Ronjerven uip., Sagbwagen.

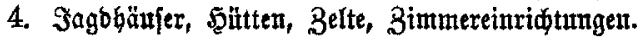

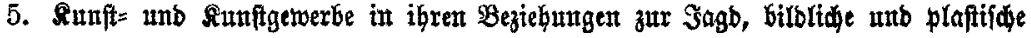
Darftellungen jeber Irt.

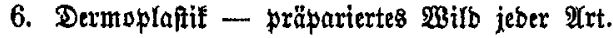

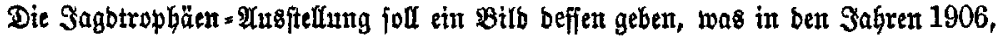
1907 unt 1908 anf basperifden Resieren ober son Mitgliebern baberijider Sagbvereine

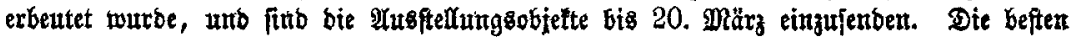
Stitue und Rolletitionen werben burd (Sbrenpreife augezeidnet.

\section{Drutfehier $=$ Bertidtigung.}

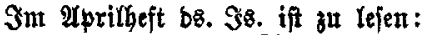

ธ. 189 3. 3 v. oben 1895 ftatt 1905 .

ธ. 196 3. 18 v. unten 48698 ftatt 48668 . 